\title{
Tailor-Made Immunochromatographic Test for the Detection of Multiple 17 $\alpha$-Methylated Anabolics in Dietary Supplements
}

\author{
Barbora Holubová ${ }^{1, *(\mathbb{D}}$, Pavla Kubešová ${ }^{1}$, Lukáš Huml ${ }^{2}$, Miroslav Vlach ${ }^{1}$ () Oldřich Lapčík $^{2}$, Michal Jurášek ${ }^{2}$ (i) \\ and Ladislav Fukal ${ }^{1}$ (D) \\ 1 Department Biochemistry and Microbiology, University of Chemistry and Technology Prague, Technická 5, \\ 16628 Prague 6, Czech Republic; paja.kuba@centrum.cz (P.K.); miroslav-vlach@seznam.cz (M.V.); \\ ladislav.fukal@vscht.cz (L.F.) \\ 2 Department of Chemistry of Natural Compounds, University of Chemistry and Technology Prague, \\ Technická 5, 16628 Prague 6, Czech Republic; lukas.huml@vscht.cz (L.H.); oldrich.lapcik@vscht.cz (O.L.); \\ michal.jurasek@vscht.cz (M.J.) \\ * Correspondence: barbora.holubova@vscht.cz
}

Citation: Holubová, B.; Kubešová, P.; Huml, L.; Vlach, M.; Lapčík, O.; Jurášek, M.; Fukal, L. Tailor-Made Immunochromatographic Test for the Detection of Multiple

$17 \alpha$-Methylated Anabolics in Dietary Supplements. Foods 2021, 10, 741.

https://doi.org/10.3390/

foods10040741

Academic Editors:

Rayco Guedes-Alonso,

Sarah Montesdeoca-Esponda and José Alberto Herrera-Melián

Received: 29 January 2021

Accepted: 30 March 2021

Published: 1 April 2021

Publisher's Note: MDPI stays neutral with regard to jurisdictional claims in published maps and institutional affiliations.

Copyright: (c) 2021 by the authors. Licensee MDPI, Basel, Switzerland. This article is an open access article distributed under the terms and conditions of the Creative Commons Attribution (CC BY) license (https:/ / creativecommons.org/licenses/by/ $4.0 /)$.

\begin{abstract}
In recent years, the undeclared presence of various anabolic androgenic steroids (AAS) in commercial supplements has been confirmed. This fact can be a potential threat to all athletes using these supplements, and therefore, there is of increased interest in the implementation of rapid methods for the detection of AAS. The presented study describes the development of an immunostrip test for the detection of multiple $17 \alpha$-methylated AAS based on direct and indirect competitive principle using gold nanoparticles as a label. As a capture reagent on test lines conjugated stanazolol to rabbit serum albumin (RSA/ST-3) was used, the intensity of color formed in the test line of the AAS-positive sample was visually distinguishable from that of negative sample within $10 \mathrm{~min}$. The optimized closed direct and indirect format of the test provided a similar visual detection limit ( 0.7 and $0.9 \mathrm{ng} / \mathrm{mL}$, respectively). The most commonly orally abused AAS ( $17 \alpha$-methyltestosterone, methandienone, methyldihydrotestosterone, oxandrolone and oxymetholone) showed a strong crossreaction. Developed immunostrips were successfully applied to analysis of artificially contaminated dietary supplements with $17 \alpha$-methylated AASs. The developed immunostrips offer potential as a useful user-friendly method for capturing suspicious dietary supplement samples with different contents of AAS at levels far below the usually used concentrations of AAS.
\end{abstract}

Keywords: immunochromatography; stanazolol; anabolic steroids (AAS); $17 \alpha$-methylated AAS; dietary supplements

\section{Introduction}

In recent years, the use of anabolic androgenic steroids (AAS) has been increasing, despite their proven negative effects. AAS increase the physical endurance and performance of athletes, which might lead to better results in sports. Other users take AAS for purely aesthetic reasons for a more effective increase in muscle mass. Nevertheless, whether they are professional or amateur athletes, the undeclared presence of AAS [1,2] in dietary supplements pose a potential threat to all of them, whether for health or doping reasons [3-5].

The basic methods for the detection of AAS include, in particular, gas or liquid chromatography combined with mass detection (GC-MS, HPLC-MS, respectively). Other commonly used methods include enzyme-linked immunosorbent assay (ELISA) [6-9]. In our recent work by Huml et al. [7], we have described the development of a group-selective immunoassay method based on stanazolol (ST)-derived polyclonal rabbit antibodies (RAb). In the latter paper [7], hapten ST-3 obtained by alkylation of the pyrazole ring showed the best performance in convenient ELISA assays. Conjugated hapten to rabbit serum albumin (RSA) was simply marked RSA/ST-3 (Supplementary Figure S1). As the result 
of this work [7], we found that the RAb 212 antibody had strong cross-reactivity (CR) for $17 \alpha$-methylated AAS in an indirect competitive ELISA setup (Figure 1). The applicability of this group-selective method was further demonstrated in a series of police-intercepted preparations containing AAS.

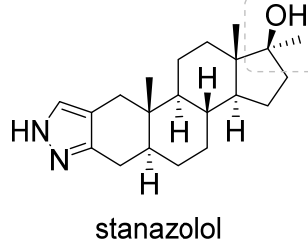
stanazolol<smiles>CCC(=O)CCC1C2CCC3CC(O)CCC3C2CCC1(C)C</smiles>

$17 \alpha$-methyldihydrotestosterone CR $97 \%$<smiles>CC1C(O)CCC2CCC3=CC(=O)CCC3(C)C21</smiles>

$17 \alpha$-methyltestosterone CR $256 \%$
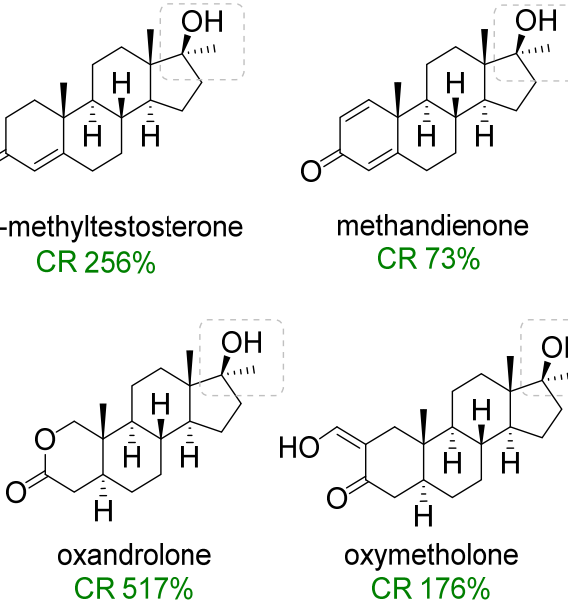

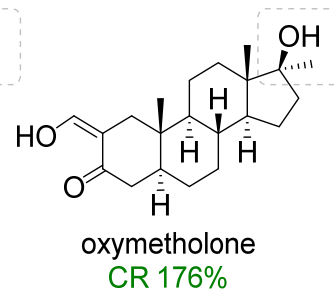

Figure 1. Molecular structures of major $17 \alpha$-methylated anabolic steroids and their cross-reactivities (CR) (CR data from Huml et al. [7]).

Based on these results, our group began to develop an immunochromatographic test (ICT) that would be well applicable in field conditions and could be useful for the immediate identification of suspect samples. The ICT (or LFIA-lateral flow immunoassay) method is based on test strips, which consist of several parts (Figure 2A) [10]. ICT method was first used to determine human chorionic gonadotropin (hCG) in urine to detect pregnancy. Due to the ease of use and commercial attractiveness of immunochromatographic assays [11], research and development in this area has expanded considerably. A wide range of analytes including viruses (e.g., hepatitis B [12], HIV [13], SARS-CoV-2 [14]), bacteria (e.g., Helicobacter pylori [15], Staphylococcus aureus [16], Salmonella [17]), toxins [18-20], pesticides [21], cancer markers [22,23], antibiotics [24,25], drugs [26,27], terpenes [28] and steroids [29-33] have been used to construct useful immunochromatographic assays.

The assay is based on the interaction of antigen with antibody as they flow through the membrane. One of the binding partners is labeled with nanoparticles (NPs). The most commonly used colloid is gold (AuNPs), because it is the most stable, does not undergo decomposition processes by light and is non-toxic $[34,35]$. The method can be divided into open and closed formats (Figure 2A). Because the enclosed has the advantage that all immunoreagents are pre-immobilized on the test strips, and only a sample needs to be added, this method is very suitable for field use. The open format is mostly used for laboratory testing and method development. Immunoreagents are applied to the membrane to produce control (CL) and test (TL) lines. Based on the visibility of one or two bands after the reaction, the results can be read visually, or the bands can be evaluated by image analysis, e.g., scanned in degrees of color intensity and measured using a suitable computer program. The evaluation of the test is described in (Figure 2B). 
A

open format

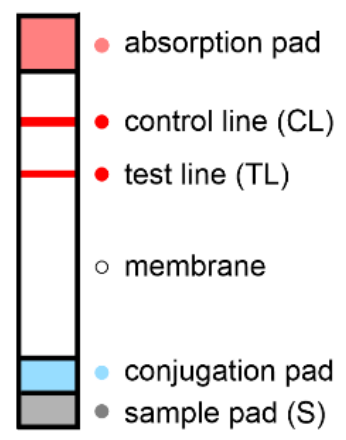

closed format

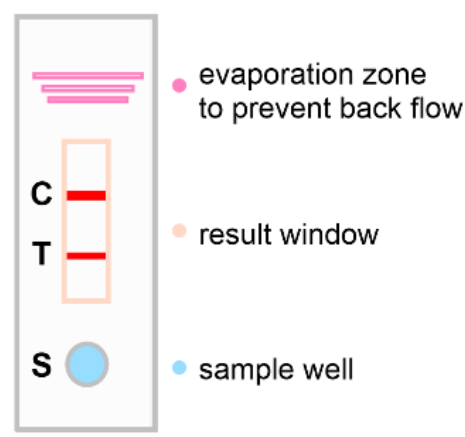

B positive negative non-functional test
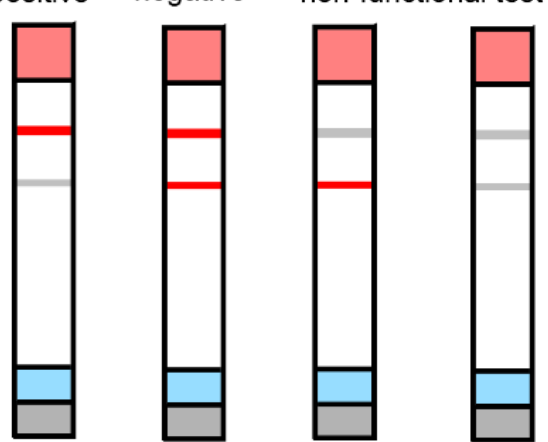

C
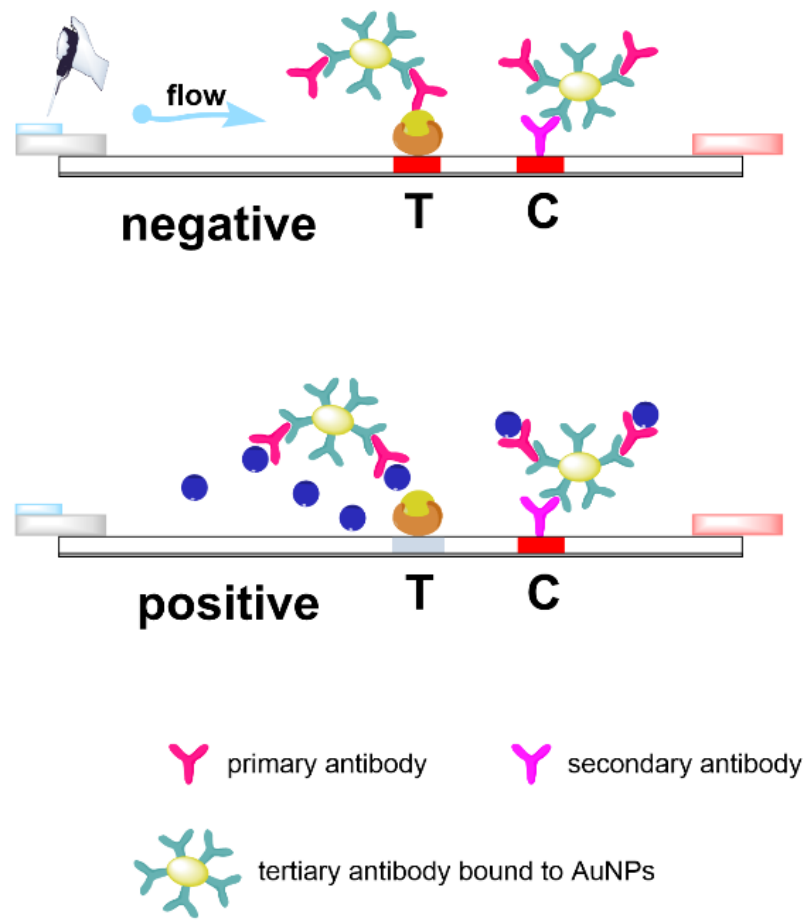
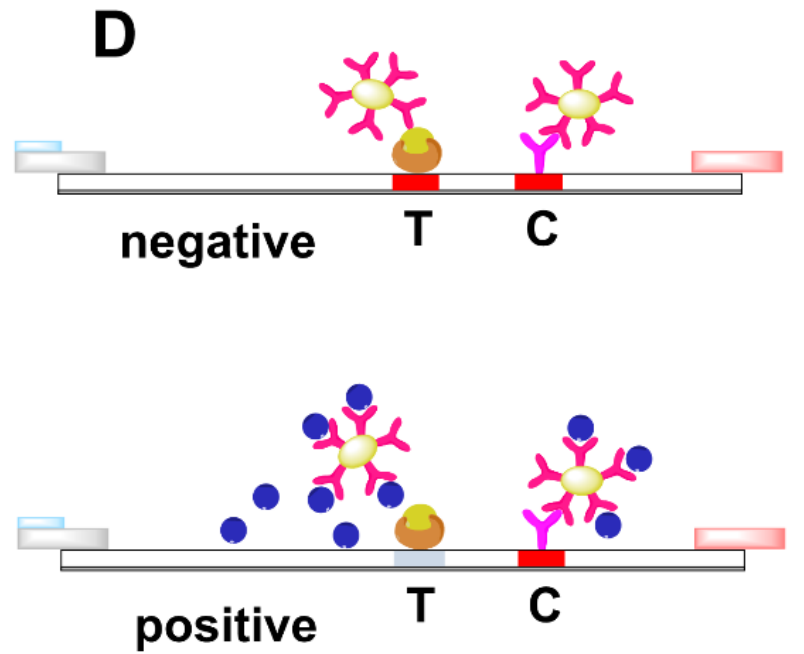

hapten bound to protein

analyte

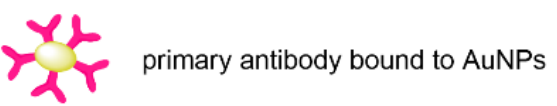

Figure 2. Test strips of immunochromatographic test (ICT) in competitive arrangement. Description of individual parts and representation of opened and closed format on panel (A); test results on panel (B); representation of indirect and direct ICT format on panels (C,D), respectively.

ICT methods have a lower sensitivity compared to the ELISA, usually increasing the detection limit by one order of magnitude [21,36,37]. Therefore, in this work, the competitive test was arranged in indirect (Figure 2C) and direct format (Figure 2D), because the method of arrangement could have the effect of reducing the detection limit of the developed method. The difference is in the labeled antibodies. In the direct format, the primary antibody (against the analyte conjugate) is labeled, while in the indirect format, a tertiary antibody is bound to the NPs, which specifically binds to the primary antibody.

In the current work, we describe the optimization of the composition of the strip test, its applicability on the detection of AAS, and successful testing of artificially contaminated dietary supplements with $17 \alpha$-methylated AAS. 


\section{Materials and Apparatus}

\subsection{Immunoreagencies}

Donkey anti-goat (DAG) antibodies, donkey antibodies against goat serum immunoglobulins, and goat anti-rabbit (GAR) antibodies, goat antibodies against rabbit serum immunoglobulins were purchased from Nordic Immunological Laboratories (Eindhoven, Netherlands); rabbit polyclonal antibodies against conjugate ST-3 (RAb 212) (primary antibody) and immobilization conjugate RSA/ST-3 were available from our previous work (Supplementary Figure S1) [7].

\subsection{Chemicals}

Bovine serum albumin (BSA), polyethylene glycol 1500 (PEG) and Tween 20 were purchased from Merck (Kenilworth, NJ, USA). Trehalose was purchased from Glentham Life Science Ltd. (Wiltshire, UK). Steroid standards were purchased from Steraloids Inc. (Newport, RI, USA) and Sigma Aldrich Corp. (St. Louis, MO, USA). Steroids were dissolved in ethanol $(96 \%)$ to a concentration of $1 \mathrm{mg} / \mathrm{mL}$ and stored at $-18{ }^{\circ} \mathrm{C}$.

\subsection{Material for ICT}

Enclosures for closed ICT format were purchased from Kinbio Tech Co., Ltd. (Shanghai, China). The membranes and pads used are summed-up in Supplementary Table S1.

\subsection{Buffers}

Borate buffers; $0.2 \mathrm{~mol} / \mathrm{L}, \mathrm{pH}$ 8.8: $22.88 \mathrm{~g}$ of borax, $0.3 \mathrm{~L}$ of deionized water; $0.1 \mathrm{~mol} / \mathrm{L}$, $\mathrm{pH}$ 8.8: $0.5 \mathrm{~L}$ of $0.2 \mathrm{~mol} / \mathrm{L}$ borate buffer, $0.5 \mathrm{~L}$ of deionized water, $5 \mathrm{~mL} 2 \%$ sodium azide; $5 \mathrm{mmol} / \mathrm{L}, \mathrm{pH}$ 8.8: $5 \mathrm{~mL}$ of $0.1 \mathrm{~mol} / \mathrm{L}$ borate buffer, $95 \mathrm{~mL}$ of deionized water, $1 \mathrm{~mL}$ of $2 \%$ sodium azide; carbonate-bicarbonate buffer, $\mathrm{pH}$ 9.6; $1.59 \mathrm{~g}$ of sodium carbonate, $2.93 \mathrm{~g}$ of sodium bicarbonate, $1 \mathrm{~L}$ deionized water; wash buffer for a solution of AuNPs with antibodies ( $5 \mathrm{mmol} / \mathrm{L}$ borate buffer, $1 \% \mathrm{BSA}$ ): $10 \mathrm{~mL}$ of $5 \mathrm{mmol} / \mathrm{L}$ of borate buffer, $0.1 \mathrm{~g} \mathrm{BSA}$; reaction buffer for ICT ( $0.1 \mathrm{~mol} / \mathrm{L}$ borate buffer, $1 \%$ BSA, $1 \%$ PEG, $1 \%$ Tween): $10 \mathrm{~mL}$ of $0.1 \mathrm{~mol} / \mathrm{L}$ borate buffer, $0.1 \mathrm{~g} \mathrm{BSA}, 0.1 \mathrm{~g}$, PEG, $100 \mu \mathrm{L} \mathrm{10 \%}$ Tween 20; storage buffer for a solution of AuNPs with antibodies ( $0.1 \mathrm{~mol} / \mathrm{L}$ borate buffer, $1 \% \mathrm{BSA}): 10 \mathrm{~mL}$ of $0.1 \mathrm{~mol} / \mathrm{L}$ borate buffer, $0.1 \mathrm{~g}$ BSA; drying buffer for ICT $(0.2 \mathrm{~mol} / \mathrm{L}$ borate buffer, $0.1 \% \mathrm{BSA}, 3 \%$ trehalose, $1 \%$ Tween 20): $10 \mathrm{~mL}$ of $0.2 \mathrm{~mol} / \mathrm{L}$ borate buffer, $0.01 \mathrm{~g}$ BSA, $0.3 \mathrm{~g}$ trehalose, $100 \mu \mathrm{L} 100$ Tween 20.

\subsection{Apparatus and Software}

CAMAG ${ }^{\circledR}$ Linomat 5 (Muttenz, Switzerland) and programmable strip cutter ZQ2002 (Kinbio Tech Co. Ltd., Shanghai, China); TotalLab program (Newcastle-upon-Tyne, UK).

\section{Experimental Section}

\subsection{Preparation of Conjugates of GAR-AuNPs and RAb-AuNPs}

The individual steps for preparing the gold nanoparticle antibody conjugate (GARAuNPs) used in this work are clearly shown in Supplementary Figure S2. GAR tertiary antibody diluted in redistilled water to a concentration of $1 \mathrm{mg} / \mathrm{mL}$, AuNPs and $5 \mathrm{mmol} / \mathrm{L}$ borate buffer was used to prepare the conjugate (direct arrangement). The ratio of these reactants in the mixture was as follows: $2 \mathrm{~mL}$ of $5 \mathrm{mmol} / \mathrm{L}$ borate buffer; $1 \mathrm{~mL}$ of AuNPs; $100 \mu \mathrm{g}$ of antibody. The same procedure for preparing a solution of AuNPs with antibody (RAb-AuNPs) for the direct arrangement was used (Supplementary Figure S2). As to the indirect arrangement, the same ratio of reactants was used. The only difference was in the selected antibody; in this case, the primary antibody RAb 212 was used.

\subsection{Preparation of Samples and Matrices}

Matrices (food supplements without the presence of AAS; verified by gas chromatography according to Stepan et al. [38]) and samples of food supplements (obtained from the B\&M Fitness Center Pelhřimov, 3D Fitness Academy Prague and the Fitness007 Prague store) were prepared as follows: $1 \mathrm{~mL}$ of $\mathrm{EtOH}$ was added to the $0.1 \mathrm{~g}$ matrix/sample weighing or $0.1 \mathrm{~mL}$ liquid sample, the mixture was shaken for $20 \mathrm{~min}$ using a multi-speed 
vortex and then stored at $4{ }^{\circ} \mathrm{C}$. To test the effect of dietary supplements on both tests, diluted ethanolic matrix extracts were applied. For ICT, they were diluted $10 \times, 50 \times, 100 \times$ and $500 \times$ in reaction buffer. To contaminate the food supplements with other AAS samples, a protein matrix (Ultrafield $100 \%$ whey protein, Scitec Nutrition) was chosen. The matrix (399 $\mathrm{mg}$ ) was contaminated by the addition of AAS as follows (see Figure 5): Mixture 1: nandrolone $(0.33 \mathrm{mg})$, methandienone $(0.33 \mathrm{mg})$ and ST $(0.33 \mathrm{mg})$. Mixture 2: nandrolone $(0.33 \mathrm{mg})$, oxymetholone $(0.33 \mathrm{mg})$ and ST $(0.33 \mathrm{mg})$. Mixture 3: nandrolone $(0.33 \mathrm{mg})$, testosterone propionate $(0.33 \mathrm{mg})$ and ST $(0.33 \mathrm{mg})$. Mixture 4: testosterone enanthate $(0.5 \mathrm{mg})$ and ST $(0.5 \mathrm{mg})$. Mixture 5 : testosterone propionate $(0.5 \mathrm{mg})$ and ST $(0.5 \mathrm{mg})$. Control: boldenone $(1 \mathrm{mg})$, dihydrotestosterone- DHT $(1 \mathrm{mg})$ and ST $(1 \mathrm{mg})$.

\subsection{Preparation of ICT Strips}

The membrane was cut from the supply roll and glued to the pad for better handling. For the open format, plastic reinforcement was used, for the closed format, laminate. After the membrane was reinforced, immunoreagents were applied to the membrane using a Linomat 5 instrument to form control (CL) and test lines (TL). Antibodies were immobilized in CL. In the case of the indirect format, DAG was diluted in $5 \mathrm{mmol} / \mathrm{L}$ borate buffer to $100 \mu \mathrm{g} / \mathrm{mL}$; in the case of the direct format, GAR was diluted in the same buffer to $150 \mu \mathrm{g} / \mathrm{mL}$. CL was applied for a closed format of $17 \mathrm{~mm}$ and for an open format of $19 \mathrm{~mm}$ from the bottom edge of the membrane. RSA/ST-3 conjugate diluted in carbonatebicarbonate buffer to a concentration of $300 \mu \mathrm{g} / \mathrm{mL}$ for the indirect and $200 \mu \mathrm{g} / \mathrm{mL}$ for the direct format was immobilized on TL (13 $\mathrm{mm}$ for closed and $15 \mathrm{~mm}$ for opened format from the edge). The resulting amount of individual immunoreagents was $2 \mu \mathrm{L}$ per $1 \mathrm{~cm}$ of the membrane (i.e., $0.8 \mu \mathrm{L}$ per one strip). The membrane, thus, treated was incubated overnight at $37^{\circ} \mathrm{C}$. The next day, other components were glued to the reinforcement to the membrane. In the case of the open format, the glass fibers as a support for the sample and for the closed format, conjugation and absorption pads were added. The conjugation and sample pad were placed in drying buffer for $1 \mathrm{~min}$ for the closed format on the first day and dried for $1 \mathrm{~h}$ at $37^{\circ} \mathrm{C}$. Its components are necessary for the correct course of the test and for the stabilization of the conjugate of AuNPs and antibodies, which are then applied to the conjugation pad using Linomat 5. For indirect format, $3 \mu \mathrm{L}$ of GAR-AuNPs and $2 \mu \mathrm{L}$ of RAb 212 antibody per strip, for direct format $3.5 \mu \mathrm{L}$ of RAb-AuNPs conjugate were applied. The plate was incubated at $37^{\circ} \mathrm{C}$ until the next day after conjugate application. In both cases, the membrane, thus, assembled was chopped with a $4 \mathrm{~mm}$ wide strip cutter.

\subsection{Open Format}

The strips of cut membrane were glued to a wooden base. The upper end of the membrane was covered with an absorbent pad for better sample uptake. A mixture of $40 \mu \mathrm{L}$ of reaction buffer, $40 \mu \mathrm{L}$ of sample and, in the case of direct arrangement, $1.5 \mu \mathrm{L}$ of RAb-AuNPs conjugate was applied to the glass fibers, $3 \mu \mathrm{L}$ of GAR-AuNPs and $2 \mu \mathrm{L}$ of $\mathrm{RAb} 212$ in the indirect arrangement.

\subsection{Closed Format}

The strips of cut membrane were fixed in plastic boxes. When fixing them, it was necessary to pay attention to the correct direction of the strips, and they should not bend. Subsequently, the box was closed. A mixture of $40 \mu \mathrm{L}$ of sample and $40 \mu \mathrm{L}$ of reaction buffer was applied to the lower window, then the test result could be observed in the second window (Figure 2A, closed format).

\subsection{Test Evaluation}

Both types of assays were evaluated visually by comparing the TL on the strip (where a steroid standard or sample was applied) against TL on the strip, where the applied solution did not contain analyte. If the TL intensity on the test strip was weaker than that of the negative control, it was a positive result. The results could also be evaluated 
semi-quantitatively by visual comparison of the sample strip with strips with different known analyte concentrations (calibration series) and, thus, to determine the approximate analyte concentration in the sample. Using the calibration series, the visual detection limit (VDL) can be determined, which is the lowest analyte concentration in the sample, reflected by the attenuation of TL on the strip to which the sample was applied against TL on the strip with no presence of the analyte. In some cases, the tests were also evaluated quantitatively using the computer program TotalLab, where the intensity of the lines was evaluated on the basis of grayscale. Their values were then plotted against the decimal logarithm of the target analyte concentration (ST). The resulting points were interpolated by a sigmoid curve (calibration curve), which can be characterized using a four-parameter regression equation (sigmoid):

$$
S=C+\left(\frac{D-C}{1+e^{-2(\alpha+\beta \cdot x)}}\right)
$$

where $S$ is greyscale, $C$ lower asymptote curve, $D$ upper asymptote curve, $\alpha$ shift of the linear part of the sigmoid curve in the coordinate system, $\beta$ slope of the linear part of the sigmoid curve, and $x$ decimal logarithm of the analyte concentration.

The limit of detection was defined as the concentration of an analyte corresponding to the maximum assay signal minus $3 \times$ standard deviation (SD) in accordance with the calibration curve (the blank was calculated from 3 parallel determinations with the absence of an analyte). The $\mathrm{IC}_{50}$ corresponded to the concentration of analyte giving $50 \%$ inhibition of the asymptotic maximum. The linear working range corresponded to the analyte concentration causing the $20-80 \%$ inhibition of the maximum assay signal.

\subsection{Cross Interactions}

Cross interactions (CR) were assessed visually after application of steroids at concentrations of 10 and $0.1 \mu \mathrm{g} / \mathrm{mL}$ by comparing the intensities of the TL bands of the individual steroids with the TL of the negative strip. The CL must always appear, if it does not appear, then the test is invalid and must be repeated. In the case of a competitive format, the TL appears only in the absence of analyte in the sample. If the analyte is present in the sample, then only the CL is visible. The steroids tested for CR are presented in Figure 1 and Figure S3. The strong CR was manifested by the disappearance of TL at both concentrations. A smaller interaction meant the disappearance of TL at a higher concentration and at a lower level only a weakening of TL. If the TL did not disappear or weaken, then no CR took place.

\section{Results and Discussion}

\subsection{Immunochromatographic Test}

After characterization of the RAb 212 antibody by indirect competitive ELISA (Huml et al. [7]), the ICT has been developed. The test strips have several parts (Figure 2A), i.e., membrane $[39,40]$, conjugation, sample and absorbent pad. The membranes can be nitrocellulose, nylon, polyethylene or Teflon. The main criteria for their selection include the size of the pores that affect the course of the reaction and the flow rate of the reagents. The conjugation pad made of glass, polyester or cellulose fibers is part of a closed format, where a conjugate of NPs with antibodies is applied. The sample application pad is made of cellulose or glass fibers. Both of these pads also serve as a filter to retain unwanted larger particles from the sample. At the end of the strip, the absorbent pad accelerates the flow of reagents through the membrane and traps excess material. A disadvantage may be the need to change the buffers used to dilute immunoreagents [41]. Both indirect and direct competitive arrangement formats in open and closed format were tested. All experiments were performed in triplicate.

\subsection{Indirect Format}

Similarly to our previous report by Fojtíková et al. [8], coloidal gold particles and GAR antibody were used to prepare GAR-AuNPs conjugate. The following conditions were chosen for the open format: DAG concentrations in CL and RSA/ST-3 in TL, both 
$100 \mu \mathrm{g} / \mathrm{mL}, 2 \mu \mathrm{L}$ RAb 212 applied to the strip, AE98 membrane, GFCP 103,000 glass fibers as sample pad and CFSP 223,000 absorbent pad. In the first experiment, the functionality of the RSA/ST-3 and GAR-AuNPs conjugate was tested. The GAR-AuNPs conjugate was applied in an amount of 3 and $5 \mu \mathrm{L}$. The best results were observed in an amount of $3 \mu \mathrm{L}$ per strip (Supplementary Figure S4A). A calibration series with a visual detection limit of $0.5 \mathrm{ng} / \mathrm{mL}$ was subsequently set up for the conditions thus selected (Supplementary Figure S4B). Furthermore, CRs of the antibody with other steroids (structures in Figure 1 and Supplementary Figure S3) were verified for this assay.

In this experiment, steroids were applied at concentrations of 0.1 and $10 \mu \mathrm{g} / \mathrm{mL}$. As can be seen from Figure 3A, $17 \alpha$-methyltestosterone, methandienone, methyldihydrotestosterone, oxandrolone and oxymetholone showed strong CR. Boldenone, boldenone benzoate and testosterone showed lower CR. Dihydrotestosterone benzoate and testosterone decanoate did not cross-interact. CR was caused by a similar structure of steroids mainly in position C17. Therefore, the greatest reactivity was with steroids that have the same groups as ST (17 $\alpha$-methyl and $\beta$-hydroxyl) at C17 position. Conversely, those that have, for example, a longer aliphatic chain at this position did not respond. The RAb 212 antibody showed the same specificity during its characterization by indirect competitive ELISA (Huml et al. [7]). Thus, the specificity of the antibody was not affected by the format of the immunochemical method used. This conclusion was confirmed in previous reports [42,43].

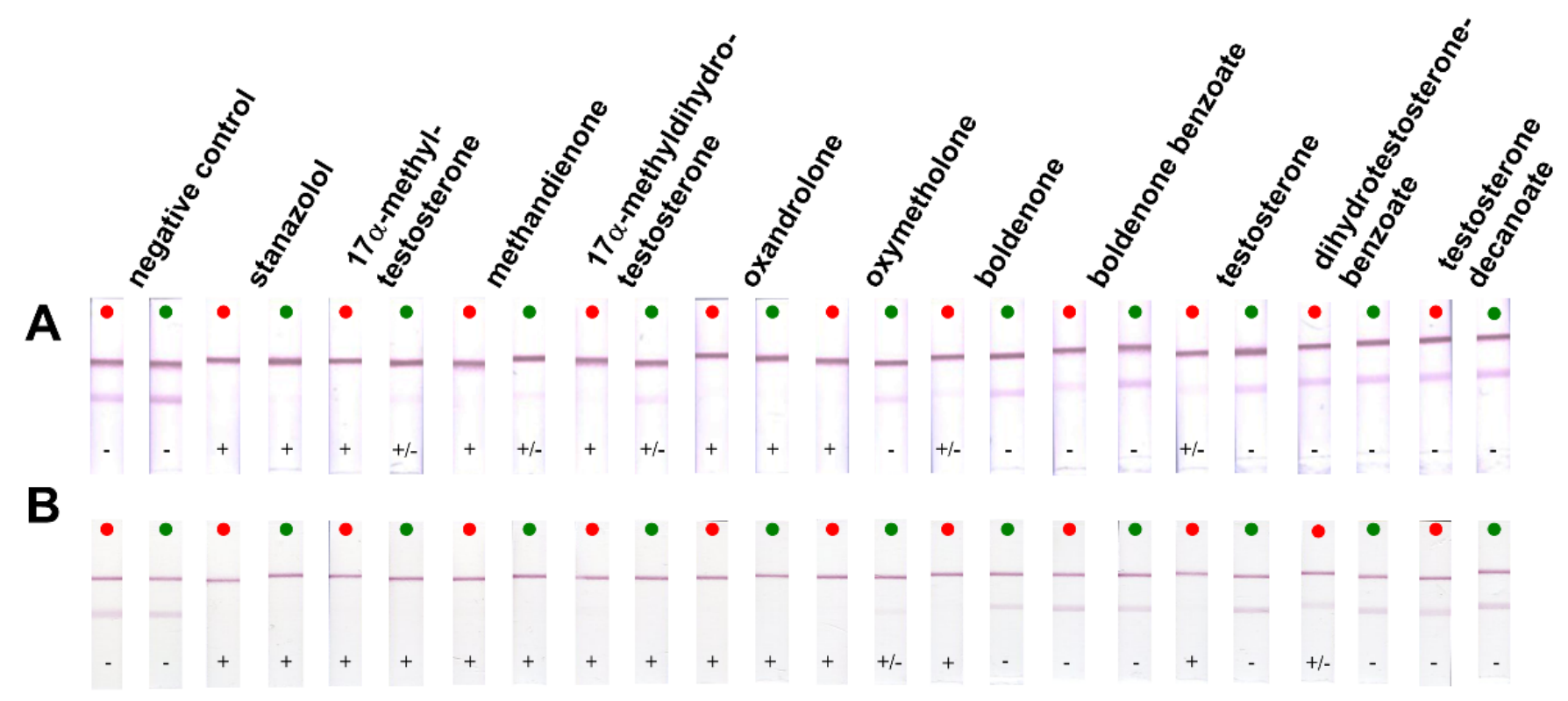

Figure 3. Cross-reactivity of selected steroids (Figure 1 and Supplementary Figure S3) in indirect (panel (A)) and direct format (panel (B)) tested at $10 \mu \mathrm{g} / \mathrm{mL}$ (red dot) and $0.1 \mu \mathrm{g} / \mathrm{mL}$ (green dot). The tests were evaluated as negative (-), suspect $(+/-)$ or positive $(+)$.

After closing the system in boxes, the visual detection deteriorated the limit by one order of magnitude. It was, therefore, necessary to test the individual conditions that affect the speed and the quality of the result, which includes the intensity and sharpness of the lines and the sufficient buoyancy of the reaction mixtures. It was a matter of selecting a suitable membrane, individual components and the concentrations of immunoreagents. All tested materials are summed-up in Supplementary Table S1, and examples of some results are shown in Supplementary Figure S5A,B. Some materials have been retained for their suitability, others have been replaced by material that has resulted in a faster and higher-quality test result. The original and new materials are depicted in Table S1. In all experiments, the concentration of DAG in CL was $100 \mu \mathrm{g} / \mathrm{mL}$. Because the concentration of $100 \mu \mathrm{g} / \mathrm{mL}$ of RSA/ST-3 in TL taken from the open format was not sufficient, higher concentrations were tested, from which $300 \mu \mathrm{g} / \mathrm{mL}$ was selected for further experiments. 
For drying on a conjugation pad the following combinations of the amount of dried GARAuNPs and RAb 212 were tested $(\mu \mathrm{L}): 3: 1,3: 2,3: 3,4: 1,4: 2,4: 3,5: 1,5: 2$ and 5:3, from which a combination of $3 \mu \mathrm{L}$ of GAR-AuNPs and $2 \mu \mathrm{L}$ of RAb 212 was selected for further experiments. As can be seen in Figure S5A, some membranes were unsuitable for this test (i.e., FF80HP, PRIMA 125) because the sample did not completely rise or it returned from the absorbent pad, and thus, the results could not be read despite the staining. Better, although not completely good, results were provided, e.g., by AE 100, where it was possible to read the results. However, the uptake was not sufficient and the reaction mixture returned from the absorbent pad, although this did not clearly affect the lines. Sufficient rise was achieved especially with AE 98 and FF120HP. The visual detection limits (VDLs) of these two membranes were then compared. Because this limit was $5 \mathrm{ng} / \mathrm{mL}$ for the AE 98 membranes used for the open format and $8 \mathrm{ng} / \mathrm{mL}$ for FF120HP, AE 98 was used in further experiments. Other significant differences were seen when testing the various absorbent pads (Supplementary Figure S5B). For these, there was a significant difference in thickness, which affected the rate of rise and the amount of reaction mixture captured. For some pads, absorption was insufficient and the mixture refluxed, leaving red streaks. Of all the pads tested, the Grade 320 and Grade 601 pads visually gave the best results. On the Grade 601 strips, the reaction mixture rose very slowly; even after $20 \mathrm{~min}$, the result could not be read. Therefore, Grade 320 was chosen as a suitable pad for further tests, which was the strongest and, therefore, absorbed the most mixture; there was no backflow of immunoreagents and the result could be read already after $10 \mathrm{~min}$. As a result, the strips were clean, free of reaction residue, and nothing affected the intensity of the lines. For other materials from Table S1, the results differed mainly in the rate of rise in the mixture.

Furthermore, various drying and reaction buffers were tested. Their composition is summarized in Table S2. It was found that for the drying buffer, better results were obtained for buffers with the addition of trehalose, which increased the stability of the components of this buffer. For both buffers, the addition of Tween 20 detergent was necessary, without which the rate of rise was slower, the strips remained red colored, and thus, it was impossible to read the results. Tween 20 serves to reduce non-specific interactions, so it is an essential part of buffers. Furthermore, various combinations of pad drying procedures were tested-only the conjugation pad was dried in the buffer, only the sample pad, or both. The drying time was also examined $-1 \times 1 \mathrm{~h}, 2 \times 1 \mathrm{~h}$ (this option was used in previous protocols described by us $[8,26])$ and $1 \times 2 \mathrm{~h}$. The best results were obtained with $0.2 \mathrm{~mol} / \mathrm{L}$ borate buffer $-0.1 \%$, BSA-3\%, trehalose- $1 \%$ Tween 20 for a drying buffer and $0.1 \mathrm{~mol} / \mathrm{L}$ borate buffer-1\%, BSA-1\%, PEG-1\% Tween 20 for reaction buffer. Drying time was shortened from the original $2 \times 1 \mathrm{~h}$ to $1 \mathrm{~h}$ with sufficient results. All original and newly selected immunoreagents and materials are summarized in Table 1.

Table 1. A summary of optimized conditions for indirect ICT formats.

\begin{tabular}{|c|c|c|}
\hline Parameter & Opened Format & Closed Format \\
\hline Concentration of DAG in CL & $100 \mu \mathrm{g} / \mathrm{mL}$ & $100 \mu \mathrm{g} / \mathrm{mL}$ \\
\hline Concentration of RSA/ST-3 in TL & $100 \mu \mathrm{g} / \mathrm{mL}$ & $300 \mu \mathrm{g} / \mathrm{mL}$ \\
\hline Amount of GAR-AuNPs & $5 \mu \mathrm{L}$ & $3 \mu \mathrm{L}$ \\
\hline Amount of RAb 212 & $2 \mu \mathrm{L}$ & $2 \mu \mathrm{L}$ \\
\hline Membrane * & AE 98 & AE 98 \\
\hline Membrane pad * & HF000MC100 & HF000MC100 \\
\hline Sample pad * & GFCP 103000 & Grade 1281 \\
\hline Conjugation pad * & $\mathrm{NA}^{\mathrm{a}}$ & Grade 6615 \\
\hline Absorption pad * & CFSP 223000 & Grade 320 \\
\hline Drying buffer & $\mathrm{NA}^{\mathrm{a}}$ & $\begin{array}{c}0.2 \mathrm{~mol} / \mathrm{L} \text { borate buffer }-0.1 \%, \mathrm{BSA}-3 \% \text {, } \\
\text { trehalose }-1 \% \text { Tween } 20\end{array}$ \\
\hline Reaction buffer & $\begin{array}{c}0.1 \mathrm{~mol} / \mathrm{L} \text { borate buffer }-1 \% \text {, BSA }-1 \% \text {, } \\
\text { PEG- } 1 \% \text { Tween } 20\end{array}$ & $\begin{array}{c}0.1 \mathrm{~mol} / \mathrm{L} \text { borate buffer }-1 \% \text {, BSA }-1 \% \text {, } \\
\text { PEG- } 1 \% \text { Tween } 20\end{array}$ \\
\hline
\end{tabular}

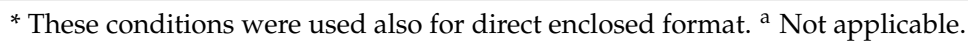


After selecting the appropriate test conditions, a calibration series with visual detection was set up limit around $1 \mathrm{ng} / \mathrm{mL}$ (Supplementary Figure S6). For its more accurate determination, amounts of $0.5,0.6,0.7,0.8,0.9$ and $1 \mathrm{ng} / \mathrm{mL}$ were further tested, of which $0.9 \mathrm{ng} / \mathrm{mL}$ was chosen as the VDL. Thus, the selection of suitable materials for the test reduced the VDL compared to $5 \mathrm{ng} / \mathrm{mL}$, which were determined at the beginning of the experiments.

The calibration series for this format was also evaluated using the computer program TotalLab. The resulting calibration curve of the logarithm of the concentration of ST on gray scale is displayed in Supplementary Figure S7. Supplementary Table S3 summarizes the characteristics of the standard ST curves (detection limit, $\mathrm{IC}_{50}$ value and linear working range). In the middle of the linear region is usually the concentration corresponding to the visual detection limit. In this case, this is equal to a concentration of $1 \mathrm{ng} / \mathrm{mL}$, which corresponds to the detection limit determined visually (i.e., $0.9 \mathrm{ng} / \mathrm{mL}$ ).

\subsection{Direct Format}

For the direct format, a conjugate of AuNPs with primary antibodies was newly synthesized (RAb-AuNPs). The functionality of this conjugate was tested in an open format, for which it was necessary to determine the amount of RAb-AuNPs conjugate, the concentration of GAR antibody in CL and RSA/ST-3 conjugate in TL. The tested amounts of RAb-AuNPs can be seen in Supplementary Figure S8A. An amount of $1.5 \mu \mathrm{L}$ was selected as suitable for further tests. The concentration of GAR in CL was determined to be $150 \mu \mathrm{g} / \mathrm{mL}$ and the conjugate RSA/ST-3 in TL to be $200 \mu \mathrm{g} / \mathrm{mL}$. Subsequently, a calibration series (Supplementary Figure S8B) was established, where it was found that the VDL is between concentrations of 0.5 and $1 \mathrm{ng} / \mathrm{mL}$. Therefore, concentrations of $0.4,0.5,0.6,0.7,0.8,0.9$ and $1 \mathrm{ng} / \mathrm{mL}$ were tested, of which a concentration of $0.6 \mathrm{ng} / \mathrm{mL}$ was chosen as the VDL. The obtained ST standard curve was nearly identical to the standard curve obtained for indirect format, as can be seen from their analytical features shown in Supplementary Table S3.

Furthermore, CRs were verified for the same steroids at the same concentrations as for the indirect assay format (see Figure 3). From the strips, it was possible to read the same results as in the indirect format, i.e., $17 \alpha$-methyltestosterone, methandienone, methyldihydrotestosterone, oxandrolone and oxymetholone showed strong CR. Boldenone, boldenone benzoate and testosterone showed lower CR; dihydrotestosterone benzoate and testosterone decanoate did not react.

After verifying the open format, the test was closed. Reagent concentrations in CL and TL were the same as for the open format; the other conditions were chosen to be the same as the indirect closed format. Only the amount of RAb-AuNPs to be dried on the conjugation pad was tested. Amounts of 1.5, 2, 2.5, 3, 3.5, 4, 4.5 and $5 \mu \mathrm{L}$ were tested. As can be seen in Supplementary Figure S9A, CL are sufficiently intense for all options, but TL is sufficiently visible for up to $3.5 \mu \mathrm{L}$ of RAb-AuNPs conjugate and was, therefore, used for further tests. This was followed by the determination of the VDL. From the calibration series (Supplementary Figure S9B), it was found that its value is below $1 \mathrm{ng} / \mathrm{mL}$; therefore, concentrations of $0.5,0.6,0.7,0.8,0.9$ and $1 \mathrm{ng} / \mathrm{mL}$ were tested of which $0.7 \mathrm{ng} / \mathrm{mL}$ was determined as the VDL. The achieved visual detection limit corresponds to the VDLs obtained in the other developed formats (visual detection limits range of $0.5-0.9 \mathrm{ng} / \mathrm{mL}$ ) and is approximately an order of magnitude higher than the detection limit of ELISA $(0.02 \mathrm{ng} / \mathrm{mL})$ in our recent work by Huml et al. [7]. This difference corresponds to previously published studies $[21,36,37]$. None of the ICT test arrangements used resulted in a reduction in the detection limit compared to another format. The indirect closed ICT format will be more appropriate for routine analysis because its cost will be lower compared to the direct format. This format requires reduced amounts of specific (primary) antibody and a "universal label" - GAR-AuNPs - which is also suitable for other ICT methods that use a specific rabbit antibody as one of the immunoreactants.

The visual detectability of the developed methods is comparable to other ICTs for the analysis of low molecular weight compounds such as methiocarb, thiabendazole, 
forchlorfenuron, robenidine or imidocarb [21,36,44-46]. At the same time, the obtained detection limit is sufficient for the detection of commonly used concentrations of AASs for the illegal fortification of dietary supplements. To date, the ICT in the field of AAS detection has been published for methyltestosterone residues in animal feed with the cut-off value $2.5 \mathrm{ng} / \mathrm{g}$ [47], testosterone in milk samples with the cut-off value $0.5 \mathrm{ng} / \mathrm{mL}$ [48] or in drinking water with the cut-off value $5 \mathrm{ng} / \mathrm{mL}$ [49]. In any previously published work, it was not possible to test a group of $17 \alpha$-methylated anabolics in one sample.

\subsection{Spiked Food Supplements Testing}

Food supplements are most often of powder or tablet nature, so it is necessary to extract them into a suitable solvent for testing. Ethanol was chosen as the solvent for sample extraction for the closed format of the indirect and direct assay settings, as well as for the ELISA [7]. For ICT, its effect on line intensity, especially on TL, was tested. EtOH was applied as $0.5,1,5,10$ and $20 \%$ solution diluted in reaction buffer for negative control. In the solutions, thus, prepared, the ST standard was subsequently diluted to a concentration of $1 \mathrm{ng} / \mathrm{mL}$ for positive control. In both cases, the respective TL of the strips was compared with either the TL on the strips with zero ST concentration (negative control) or with the TL on the strips with $1 \mathrm{ng} / \mathrm{mL} \mathrm{ST}$ concentration (positive control) in the absence of EtOH. From the results, it was found that for the indirect format it is sufficient to dilute the $\mathrm{EtOH}$ to a $5 \%$ solution, but for the direct format, dilution is necessary to $1 \%$ solution (Supplementary Figure S10A). Ethanol extracts of food supplements (matrices-Section 3.2) were diluted $10 \times, 50 \times, 100 \times$ and $500 \times$, i.e., to solutions with $10,2,1$ and $0.5 \% \mathrm{EtOH}$ content. When comparing TL intensities, it was found that for the indirect format, the lines are not affected by the $50 \times$ diluted $(2 \% \mathrm{EtOH})$ matrix solution and for the direct format by the $100 \times$ diluted $(1 \%$ EtOH) matrix solution (Supplementary Figure S10B). Therefore, the dilution of ethanol extracts of real samples to $1 \%$ solutions was chosen, where no effect of matrix or EtOH on any of the developed test formats should be recorded.

Two sets of artificially contaminated samples were tested. Prior to the analysis, the effect of ten food supplement matrices (Supplementary Table S4) was tested [50]. No effect on the result was observed when samples $100 \times$ diluted were applied (Supplementary Figure S11).

An assembled indirect and direct open format ICT assay was used for testing (Figure 4). In the first set, matrices of food supplements (Supplementary Table S4) were artificially contaminated (Section 3.2) with the same concentration of ST. 


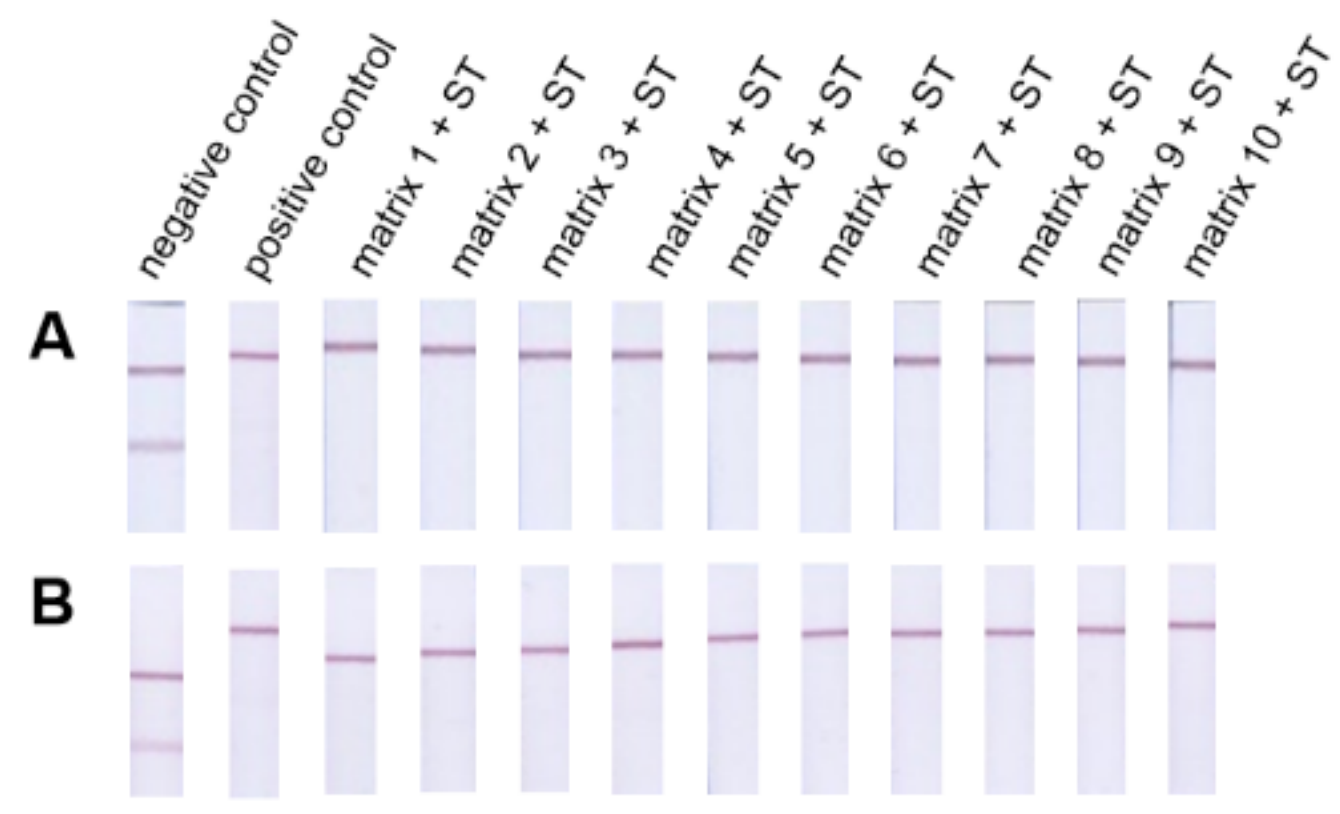

Figure 4. Spiked real supplements with ST (diluted $100 \times$ ). The method was tested in both formats, i.e., indirect (panel (A)) and direct format (panel (B)).

Ethanol extracts of the supplements (without ST) were diluted $100 \times$ (dilution recommended for sample preparation for assembled ICT assays) and analyzed by both assay formats. The resulting assay lines were visually compared to the assay line obtained for the negative control (experiment performed in reaction buffer only), and no difference in line intensity and quality was noted. Thus, the EtOH extracts of the supplements do not affect the assembled ICT assay formats, and the chosen sample preparation is suitable for further experiments.

Subsequent analysis of $100 \times$ diluted EtOH extracts of artificially contaminated food supplements did not reveal a visually visible test line in any case, and all samples can be considered positive. Then, $250 \times$ dilute $\mathrm{EtOH}$ extracts were tested (at this dilution the concentration of ST in the EtOH extract is around the visual detection limit), and even in these analyses, the test line did not appear on all prepared strips, and thus, all samples can be marked as positive again (Supplementary Figure S12).

The second set of artificially contaminated samples contained various combinations of AAS (Section 3.2) selected based on the article [51] and recommended combinations by the user [52,53] or AAS that did not cross-react at the concentrations we tested (Figure 5). On hundred-fold diluted $\mathrm{EtOH}$ extracts of the prepared samples were prepared, and the resulting test lines were visually observed. Mixtures 1-5 and the sample with ST did not show a test line, and samples can be considered positive.

A visible test line was observed for samples containing boldenone and DHT. The resulting test lines were attenuated compared to the negative control test line. Thus, the antibody used shows $\mathrm{CR}$ at such high concentrations of AAS, which are used in real cases. This can be used if we use a two-strip box for sample analysis. In this box, one strip is used as a negative control and the other strip for sample analysis. It is, then, possible to visually monitor the attenuation of the test line in the sample compared to the test line in the control. In this case, the sample can be marked as positive. 


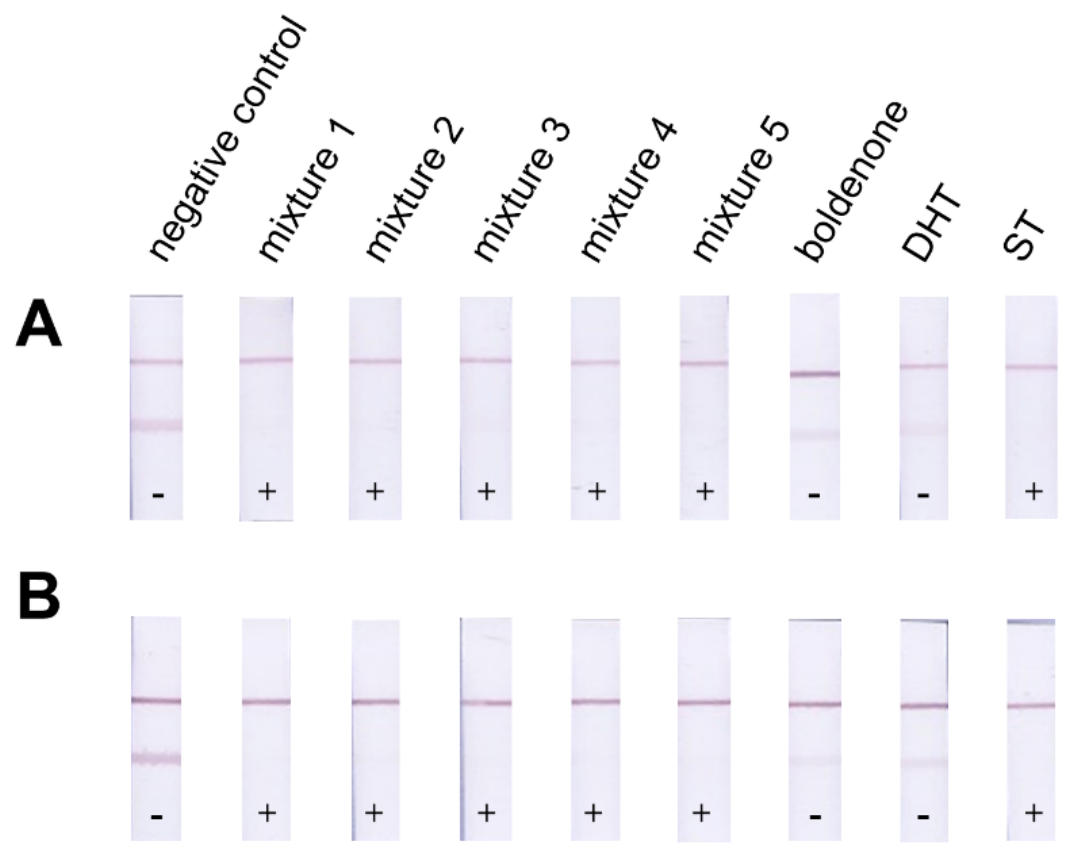

Figure 5. Result of artificially contaminated by indirect (panel (A)) and direct format (panel (B)).

Contaminated dietary supplements found on the market have different contents of anabolic steroids [54-56]. However, the usual concentration is in the order of hundreds to tens of thousands of milligrams per kilogram. Therefore, this user-friendly method is very suitable for capturing suspicious samples.

\section{Conclusions}

Taken together, superior immunochromatographic tool for the determination of AAS containing $17 \alpha$-methylated group was successfully developed. The presented study demonstrated the potential of using the colloidal gold nanoparticles as a tracer to provide visual evidence of the presence of AASs in dietary supplements within $10 \mathrm{~min}$. To our knowledge, this is the first work using a single antibody in an immunochromatographic assay to determine many anabolic steroids for detection in dietary supplements. Semi-quantitative visual evaluation of the closed format of immunostrip provided the detection limit about $1 \mathrm{ng} / \mathrm{mL}$. This concentration is far below the usually found concentration of AAS in contaminated dietary supplements. The functionality of the methods was verified by the analysis of real and artificially contaminated samples. Immunochromatographic assays are still solely screening methods. Therefore, it is always necessary to subject pre-positive test samples obtained by ICT to the other instrumental methods (GC-MS, HPLC-MS), which are, in fact, irreplaceable in the confirmation of the preliminary results, thus, obtained.

Supplementary Materials: The following are available online at https:/ /www.mdpi.com/article/ 10.3390/foods10040741/s1, Figure S1: Chemical structures of stanazolol haptene (ST-3) and its conjugate with RSA (RSA/ST-3). By immunization of rabbit, group selective polyclonal antibodies (RAb 212) were obtained, Figure S2: Procedure for the preparation of colloidal RAb 212/AuNPs solution, Figure S3: Tested steroids with low CR, Figure S4: Selection of the applied amount of GAR-AuNPs on panel A and the calibration series for indirect open format ( $3 \mu \mathrm{L}$ GAR-AuNPs were applied) on panel B, Table S1: Original and newly selected test materials for immunochromatographic test (closed format), including criteria in which the individual materials differed, Figure S5: Some results of tested membranes (panel A) and absorbent pads (panel B) for indirect closed format, Table S2: Summary of tested drying and reaction buffers, Figure S6: Calibration series for indirect closed format (3 $\mu \mathrm{L}$ GAR-AuNPs were applied), Figure S7: Calibration curve for indirect ICT format, Table S3: Characteristics of ST standard curves for indirect and direct format, Figure S8: Selection of the applied amount of RAb-AuNPs on panel A and the calibration series for direct open format 
(1.5 $\mu \mathrm{L}$ RAb-AuNPs were applied) on panel B, Figure S9: Tested amounts of applied RAb-AuNPs for closed format (panel A) and calibration series for direct closed format ( $3.5 \mu \mathrm{L}$ of RAb-AuNPs was applied; panel B), Figure S10: Testing of extraction solvent (panel A) and matrix effect (panel B) on the functionality of RAb 212 antibody, Table S4: Matrices used for contamination with AAS, Figure S11: Tested effect of selected matrices in indirect (panel A) and direct format (panel B) opened ICT format. The designation of the matrices is given above in Table S4, Figure S12: Tested selected matrices with the addition of ST with $250 \times$ dilution; indirect (panel A) and direct (panel B) opened ICT format.

Author Contributions: B.H., O.L. and L.F., methodology; B.H., L.F. and O.L., validation; M.J., formal analysis; B.H., P.K., L.H. and M.V., investigation; O.L., resources; M.J. and B.H., writing and original draft preparation; O.L. and L.F., review and editing; M.J., visualization; B.H. and L.F., supervision. All authors have read and agreed to the published version of the manuscript.

Funding: This work was supported by internal grant from the budget for the implementation of the activities of the Institutional Plan of the UCT Prague in 2020 and grant No. A1_FPBT_2020_004.

Acknowledgments: We thank to Irena Dražilová for administrative support regarding this project.

Conflicts of Interest: The authors declare no conflict of interest.

\section{References}

1. Geyer, H.; Parr, M.K.; Mareck, U.; Reinhart, U.; Schrader, Y.; Schanzer, W. Analysis of non-hormonal nutritional supplements for anabolic-androgenic steroids-results of an international study. Int. J. Sports Med. 2004, 25, 124-129. [CrossRef]

2. De Cock, K.J.; Delbeke, F.T.; Van Eenoo, P.; Desmet, N.; Roels, K.; De Backer, P. Detection and determination of anabolic steroids in nutritional supplements. J. Pharm. Biomed. Anal. 2001, 25, 843-852. [CrossRef]

3. Walpurgis, K.; Thomas, A.; Geyer, H.; Mareck, U.; Thevis, M. Dietary supplement and food tontaminations and their implications for doping controls. Foods 2020, 9, 1012. [CrossRef] [PubMed]

4. Martinez-Sanz, J.M.; Sospedra, I.; Ortiz, C.M.; Baladia, E.; Gil-Izquierdo, A.; Ortiz-Moncada, R. Intended or unintended doping? A review of the presence of doping substances in dietary supplements used in sports. Nutrients 2017, 9, 1093. [CrossRef]

5. Baume, N.; Mahler, N.; Kamber, M.; Mangin, P.; Saugy, M. Research of stimulants and anabolic steroids in dietary supplements. Scand. J. Med. Sci. Sports 2006, 16, 41-48. [CrossRef]

6. Jurášek, M.; Göselová, S.; Mikšátková, P.; Holubová, B.; Vyšatová, E.; Kuchař, M.; Fukal, L.; Lapčík, O.; Drašar, P. Highly sensitive avidin-biotin ELISA for detection of nandrolone and testosterone in dietary supplements. Drug Test. Anal. 2017, 9, 553-560. [CrossRef] [PubMed]

7. Huml, L.; Havlová, D.; Longin, O.; Staňková, E.; Holubová, B.; Kuchař, M.; Prokudina, E.; Rottnerová, Z.; Zimmermann, T.; Drašar, P.; et al. Stanazolol derived ELISA as a sensitive forensic tool for the detection of multiple $17 \alpha$-methylated anabolics. Steroids 2020, 155, 108550. [CrossRef]

8. Fojtíková, L.; Fukal, L.; Blažková, M.; Sýkorová, S.; Kuchař, M.; Mikšátková, P.; Lapčík, O.; Holubová, B. Development of enzyme-linked immunosorbent assay for determination of boldenone in dietary supplements. Food Anal. Methods 2016, 9, 3179-3186. [CrossRef]

9. Sýkorová, S.; Fojtíková, L.; Kuchař, M.; Mikšátková, P.; Karamonová, L.; Fukal, L.; Lapčík, O.; Holubová, B. Sensitive enzyme immunoassay for screening methandienone in dietary supplements. Food Addit. Contam. Part. A 2018, 35, 1653-1661. [CrossRef] [PubMed]

10. Urusov, A.E.; Petrakova, A.V.; Zherdev, A.V.; Dzantiev, B.B. "Multistage in one touch" design with a universal labelling conjugate for high-sensitive lateral flow immunoassays. Biosens. Bioelectron. 2016, 86, 575-579. [CrossRef]

11. Agnamey, P.; Sarfati, C.; Pinel, C.; Rabodoniriina, M.; Kapel, N.; Dutoit, E.; Garnaud, C.; Diouf, M.; Garin, J.F.; Totet, A.; et al. Evaluation of four commercial rapid immunochromatographic assays for detection of Cryptosporidium antigens in stool samples: A blind multicenter trial. J. Clin. Microbiol. 2011, 49, 1605-1607. [CrossRef] [PubMed]

12. Song, L.-W.; Wang, Y.-B.; Fang, L.-L.; Wu, Y.; Yang, L.; Chen, J.-Y.; Ge, S.-X.; Zhang, J.; Xiong, Y.-Z.; Deng, X.-M.; et al. Rapid fluorescent lateral-flow immunoassay for hepatitis B virus genotyping. Anal. Chem. 2015, 87, 5173-5180. [CrossRef] [PubMed]

13. Khlebtsov, B.N.; Tumskiy, R.S.; Burov, A.M.; Pylaev, T.E.; Khlebtsov, N.G. Quantifying the numbers of gold nanoparticles in the test zone of lateral flow immunoassay strips. ACS Appl. Nano Mater. 2019, 2, 5020-5028. [CrossRef]

14. Nicol, T.; Lefeuvre, C.; Serri, O.; Pivert, A.; Joubaud, F.; Dubée, V.; Kouatchet, A.; Ducancelle, A.; Lunel-Fabiani, F.; Le GuillouGuillemette, H. Assessment of SARS-CoV-2 serological tests for the diagnosis of COVID-19 through the evaluation of three immunoassays: Two automated immunoassays (Euroimmun and Abbott) and one rapid lateral flow immunoassay (NG Biotech). J. Clin. Virol. 2020, 129, 104511. [CrossRef] [PubMed]

15. Karakus, C.; Salih, B.A. Comparison of the lateral flow immunoassays (LFIA) for the diagnosis of Helicobacter pylori infection. J. Immunol. Methods 2013, 396, 8-14. [CrossRef] [PubMed]

16. Wiriyachaiporn, S.; Howarth, P.H.; Bruce, K.D.; Dailey, L.A. Evaluation of a rapid lateral flow immunoassay for Staphylococcus aureus detection in respiratory samples. Diagnostic Microbiology and Infectious Disease 2013, 75, 28-36. [CrossRef] [PubMed] 
17. Li, J.; Ma, B.; Fang, J.; Zhi, A.; Chen, E.; Xu, Y.; Yu, X.; Sun, C.; Zhang, M. Recombinase polymerase amplification (RPA) combined with lateral flow immunoassay for rapid detection of Salmonella in food. Foods 2020, 9, 27. [CrossRef]

18. Upadhyay, N.; Nara, S. Lateral flow assay for rapid detection of Staphylococcus aureus enterotoxin A in milk. Microchem. J. 2018, 137, 435-442. [CrossRef]

19. Zvereva, E.A.; Hendrickson, O.D.; Zherdev, A.V.; Dzantiev, B.B. Immunochromatographic tests for the detection of microcystin-LR toxin in water and fish samples. Anal. Methods 2020, 12, 392-400. [CrossRef]

20. Pan, M.; Ma, T.; Yang, J.; Li, S.; Liu, S.; Wang, S. Development of lateral flow immunochromatographic assays using colloidal Au sphere and nanorods as signal marker for the determination of zearalenone in cereals. Foods 2020, 9, 281. [CrossRef]

21. Blažková, M.; Micková-Holubová, B.; Rauch, P.; Fukal, L. Immunochromatographic colloidal carbon-based assay for detection of methiocarb in surface water. Biosens. Bioelectron. 2009, 25, 753-758. [CrossRef]

22. Bayoumy, S.; Hyytiä, H.; Leivo, J.; Talha, S.M.; Huhtinen, K.; Poutanen, M.; Hynninen, J.; Perheentupa, A.; Lamminmäki, U.; Gidwani, K.; et al. Glycovariant-based lateral flow immunoassay to detect ovarian cancer-associated serum CA125. Commun. Biol. 2020, 3, 1-7. [CrossRef] [PubMed]

23. Fang, C.C.; Chou, C.C.; Yang, Y.Q.; Wei-Kai, T.; Wang, Y.T.; Chan, Y.H. Multiplexed detection of tumor markers with multicolor polymer dot-based immunochromatography test strip. Anal. Chem. 2018, 90, 2134-2140. [CrossRef] [PubMed]

24. Berlina, A.N.; Bartosh, A.V.; Zherdev, A.V.; Xu, C.L.; Dzantiev, B.B. Development of immunochromatographic assay for determination of tetracycline in human serum. Antibiotics 2018, 7, 99. [CrossRef] [PubMed]

25. Hendrickson, O.D.; Zvereva, E.A.; Shanin, I.A.; Zherdev, A.V.; Tarannum, N.; Dzantiev, B.B. Highly sensitive immunochromatographic detection of antibiotic ciprofloxacin in milk. Appl. Biochem. Microbiol. 2018, 54, 670-676. [CrossRef]

26. Fojtíková, L.; Šuláková, A.; Blažková, M.; Holubová, B.; Kuchař, M.; Mikšátková, P.; Lapčík, O.; Fukal, L. Lateral flow immunoassay and enzyme linked immunosorbent assay as effective immunomethods for the detection of synthetic cannabinoid JWH-200 based on the newly synthesized hapten. Toxicol. Rep. 2018, 5, 65-75. [CrossRef] [PubMed]

27. Wennig, R.; Moeller, M.R.; Haguenoer, J.M.; Marocchi, A.; Zoppi, F.; Smith, B.L.; de la Torre, R.; Carstensen, C.A.; Goerlach-Graw, A.; Schaeffler, J.; et al. Development and evaluation of immunochromatographic rapid tests for screening of cannabinoids, cocaine, and opiates in urine. J. Anal. Toxicol. 1998, 22, 148-155. [CrossRef]

28. Zhang, Y.; Xiao, W.; Kong, H.; Cheng, J.J.; Yan, X.; Zhang, M.L.; Wang, Q.G.; Qu, H.H.; Zhao, Y.A. Highly sensitive immunochromatographic strip test for rapid and quantitative detection of Saikosaponind. Molecules 2018, 23, 338. [CrossRef] [PubMed]

29. Wang, M.; Guo, L.; Yu, M.; Zhao, H. The application of a lateral flow immunographic assay to rapidly test for dexamethasone in commercial facial masks. Anal. Bioanal. Chem. 2019, 411, 5703-5710. [CrossRef] [PubMed]

30. Samsonova, J.V.; Safronova, V.A.; Osipov, A.P. Pretreatment-free lateral flow enzyme immunoassay for progesterone detection in whole cows milk. Talanta 2015, 132, 685-689. [CrossRef]

31. Oh, H.K.; Kim, J.W.; Kim, J.M.; Kim, M.G. High sensitive and broad-range detection of cortisol in human saliva using a trap lateral flow immunoassay (trapLFI) sensor. Analyst 2018, 143, 3883-3889. [CrossRef] [PubMed]

32. Liu, L.Q.; Peng, C.F.; Jin, Z.Y.; Xu, C.L. Development and evaluation of a rapid lateral flow immunochromatographic strip assay for screening 19-nortestosterone. Biomed. Chromatogr. 2007, 21, 861-866. [CrossRef] [PubMed]

33. Yao, X.L.; Wang, Z.H.; Dou, L.N.; Zhao, B.X.; He, Y.X.; Wang, J.L.; Sun, J.; Li, T.; Zhang, D.H. An innovative immunochromatography assay for highly sensitive detection of 17 beta-estradiol based on an indirect probe strategy. Sens. Actuators B Chem. 2019, 289, 48-55. [CrossRef]

34. Lou, S.; Ye, J.Y.; Li, K.Q.; Wu, A.G. A gold nanoparticle-based immunochromatographic assay: The influence of nanoparticulate size. Analyst 2012, 137, 1174-1181. [CrossRef]

35. Razo, S.C.; Panferova, N.A.; Panferov, V.G.; Safenkova, I.V.; Drenova, N.V.; Varitsev, Y.A.; Zherdev, A.V.; Pakina, E.N.; Dzantiev, B.B. Enlargement of gold nanoparticles for sensitive immunochromatographic diagnostics of potato Brown Rot. Sensors 2019, 19, 153. [CrossRef] [PubMed]

36. Blažková, M.; Rauch, P.; Fukal, L. Strip-based immunoassay for rapid detection of thiabendazole. Biosens. Bioelectron. 2010, 25, 2122-2128. [CrossRef]

37. Hua, X.D.; Yang, J.F.; Wang, L.M.; Fang, Q.K.; Zhang, G.P.; Liu, F.Q. Development of an enzyme linked immunosorbent assay and an immunochromatographic assay for detection of organophosphorus pesticides in different agricultural products. PLoS ONE 2012, 7, e53099. [CrossRef]

38. Stepan, R.; Cuhra, P.; Barsova, S. Comprehensive two-dimensional gas chromatography with time-of-flight mass spectrometric detection for the determination of anabolic steroids and related compounds in nutritional supplements. Food Addit. Contam. Part. A 2008, 25, 557-565. [CrossRef]

39. Huang, X.L.; Aguilar, Z.P.; Xu, H.Y.; Lai, W.H.; Xiong, Y.H. Membrane-based lateral flow immunochromatographic strip with nanoparticles as reporters for detection: A review. Biosens. Bioelectron. 2016, 75, 166-180. [CrossRef]

40. Lee, J.Y.; Kim, Y.A.; Kim, M.Y.; Lee, Y.T.; Hammock, B.D.; Lee, H.S. Importance of membrane selection in the development of immunochromatographic assays for low-molecular weight compounds. Anal. Chim. Acta 2012, 757, 69-74. [CrossRef]

41. Jones, K. FUSION 5: A new platform for lateral flow immunoassay tests. Lateral Flow Immunoass. 2009, 115-129. [CrossRef] 
42. Girotti, S.; Eremin, S.; Montoya, A.; Moreno, M.J.; Caputo, P.; D’Elia, M.; Ripani, L.; Romolo, F.S.; Maiolini, E. Development of a chemiluminescent ELISA and a colloidal gold-based LFIA for TNT detection. Anal. Bioanal. Chem. 2010, 396, 687-695. [CrossRef] [PubMed]

43. Šuláková, A.; Fojtíková, L.; Holubová, B.; Bártová, K.; Lapčík, O.; Kuchař, M. Two immunoassays for the detection of 2C-B and related hallucinogenic phenethylamines. J. Pharmacol. Toxicol. Methods 2019, 95, 36-46. [CrossRef] [PubMed]

44. Suárez-Pantaleón, C.; Wichers, J.; Abad-Somovilla, A.; van Amerongen, A.; Abad-Fuentes, A. Development of an immunochromatographic assay based on carbon nanoparticles for the determination of the phytoregulator forchlorfenuron. Biosens. Bioelectron. 2013, 42, 170-176. [CrossRef] [PubMed]

45. Lin, L.; Song, S.; Wu, X.; Liu, L.; Kuang, H.; Xiao, J.; Xu, C. Determination of robenidine in shrimp and chicken samples using the indirect competitive enzyme-linked immunosorbent assay and immunochromatographic strip assay. Analyst 2021, 146, 721-729. [CrossRef] [PubMed]

46. Xu, X.; Wang, Z.; Guo, L.; Xu, X.; Wu, A.; Kuang, H.; Sun, L.; Song, S.; Xu, C. Sensitive lateral flow immunoassay for the residues of imidocarb in milk and beef samples. ACS Omega 2021, 6, 2559-2569. [CrossRef]

47. Kong, N.; Song, S.; Peng, J.; Liu, L.; Kuang, H.; Xu, C. Sensitive, fast, and specific immunoassays for methyltestosterone detection. Sensors 2015, 15, 10059-10073. [CrossRef] [PubMed]

48. Wang, Z.; Zou, S.; Xing, C.; Song, S.; Liu, L.; Xu, C. Preparation of a monoclonal antibody against testosterone and its use in development of an immunochromatographic assay. Food Agric. Immunol. 2016, 27, 547-558. [CrossRef]

49. Xing, C.; Liu, L.; Song, S.; Feng, M.; Kuang, H.; Xu, C. Ultrasensitive immunochromatographic assay for the simultaneous detection of five chemicals in drinking water. Biosens. Bioelectron. 2015, 66, 445-453. [CrossRef] [PubMed]

50. Holubová, B.; Mikšátková, P.; Kuchař, M.; Karamonová, L.; Lapčík, O.; Fukal, L. Immunochemical techniques for anabolic androgenic steroid: Matrix effects study for food supplements. Eur. Food Res. Technol. 2019, 245, 1011-1019. [CrossRef]

51. Hernandez-Guerra, A.I.; Tapia, J.; Menendez-Quintanal, L.M.; Lucena, J.S. Sudden cardiac death in anabolic androgenic steroids abuse: Case report and literature review. Forensic. Sci. Res. 2019, 4, 267-273. [CrossRef] [PubMed]

52. Available online: https://gymporn.cz/sestavovani-kury (accessed on 17 December 2020).

53. Steroidové Cykly. Available online: http:/ / steroidy.szm.com/cykly.html (accessed on 17 December 2020).

54. Potravinářská Inspekce Zakázala Doplněk Stravy z USA s Šesti Nepovolenými Látkami Včetně Anabolických Steroidů a Léčiv. Available online: https://www.szpi.gov.cz/clanek/potravinarska-inspekce-zakazala-doplnek-stravy-z-usa-s-sestinepovolenymi-latkami-vcetne-anabolickych-steroidu-a-leciv.aspx?q=JmNobnVtPTEmaGw9dGVzdG9zdGVyb24\%3d (accessed on 17 December 2020).

55. Potravinářská Inspekce Zakázala Potravinu s Anabolickým Steroidem. Available online: https://www.szpi.gov.cz/clanek/ potravinarska-inspekce-zakazala-potravinu-s-anabolickym-steroidem.aspx (accessed on 17 December 2020).

56. Průběžné Výsledky Kontroly Doplňků Pro Sportovce: Největší Problémy Jsou s Označováním, Anabolika Zatím Pouze ve Dvou Výrobcích. Available online: https://www.szpi.gov.cz/clanek/prubezne-vysledky-kontroly-doplnku-pro-sportovce-nejvetsiproblemy-jsou-s-oznacovanim-anabolika-zatim-pouze-ve-dvou-vyrobcich.aspx?q=JmhsPWFuYWJvbGlrYcKo (accessed on 17 December 2020). 